\title{
EMISSIONS TRADING AS AN APPROACH FOR REDUCING THE COST OF POLLUTION ABATEMENT
}

\author{
Hiroaki Takiguchi ${ }^{1}$ and J. Wayland Eheart ${ }^{2}$ \\ ${ }^{1}$ Member of JSCE, Ministry of the Environment, Government of Japan \\ (1-2-2 Kasumigaseki, Chiyoda-ku, Tokyo, 100-8975, Japan) \\ ${ }^{2}$ Professor, Department of Civil and Environmental Engineering, University of Illinois at Urbana-Champaign \\ (3217 Newmark Civil Engineering Laboratory, 205 North Mathews Avenue, Urbana, Illinois 61801, USA)
}

\begin{abstract}
Emissions trading can be a cost-efficient approach to reduce pollutants. This paper analyzes six examples of emissions trading programs implemented in the U.S. The analysis showed that most of the programs adopted emission permits and a grandfathering approach as well as restrictions for not creating hot spots. It also showed that emissions trading programs depend on several factors such as less restriction on transaction, credibility and transparency, and flexibility. Based on the lessons, the paper discusses possibility of emission trading programs in Japan and an emissions trading program for the reduction of water pollutants flowing into enclosed sea areas in Japan.
\end{abstract}

Key Words: cap-and-trade, emission permit and ambient permit, hot spot, grandfathering

\section{INTRODUCTION}

Nowadays, there are a variety of environmental issues ranging from classic-vital local air and water pollution problems to global issues such as climate change and ozone depletion. In order to address those problems, several types of environmental policies have been implemented. The most common and traditional approach is called "command-and-control", which requires each source to discharge pollutants below an emission (effluent) standard. In Japan, this approach has been common under the Air Pollution Control Law (1968) and the Water Pollution Control Law (1970). Emitters are required to meet the standards by installing control equipment, diminishing operation times, modifying manufacturing processes, and selecting environmental-friendly materials. In general, "command- and-control" approaches have been effective in improving environmental quality, but some of them have been criticized as inefficient, because they impose uniform standards on emitters whose capacities for, and marginal cost of, treating pollutants are very different.

Under such circumstances, emissions trading has been considered a cost-efficient way to achieve simultaneously both environmental protection and economic efficiency. It has proved to be a flexible way to curtail pollutants, allowing aggregate emissions standards to be met at lower costs.
Because of this trait, emissions trading has drawn favorable attention in recent years, first in the North America, and subsequently in the rest of the world, including Japan. The most famous example of emissions trading is the sulfur dioxide $\left(\mathrm{SO}_{2}\right)$ allowance trading program under the 1990 U.S. Clean Air Act Amendments (CAAA). The $\mathrm{SO}_{2}$ allowance trading program is a nationwide (US) emissions trading approach and has contributed to reducing $\mathrm{SO}_{2}$ emissions reductions costs at the US national level so far.

In addition, emissions trading is currently being discussed as one of the more promising approaches to reduce greenhouse gases. Reducing greenhouse gases, in particular $\mathrm{CO}_{2}$, is an imperative issue in tackling global warming. Since $\mathrm{CO}_{2}$ is emitted anywhere from the combustion of fossil fuels, controlling the emissions has a direct bearing on the economy and therefore should be realized at lower costs, if possible. Emissions trading can play a significant role in addressing this challenging issue. In fact, the Kyoto Protocol stipulates a world-wide emissions trading for the signatories to reduce greenhouse gas emissions cost-effectively.

The objectives of this report are to review emissions trading programs, to clarify the keys for success in designing and implementing them, and to discuss the applicability of the program to Japan. Emissions trading programs have not been implemented at national and local levels in Japan. 
Therefore, this paper is offered to present and explore the frontier of environmental research on this new environmental approach.

\section{CONCEPTS OF EMISSIONS TRADING}

The concept of emissions trading, and the perception that it can realize a cost-efficient allocation of pollutant emissions, initially appeared more than thirty years ago. Dales ${ }^{1)}$ conceptualizes emissions trading as the most cost-efficient way to deal with environmental problems, citing the example of improving water quality in Lake Ontario. Dales' idea includes key concepts in designing emissions trading programs: establishing an aggregate level of discharge that meets an environmental requirement, determining the total number and characteristics of the permits to meet the environmental goal, and allocating the emission permits to emitters. A well-known method of allocating the initial permits is grandfathering, which provides existing emitters permits free of charge. Once the program launches after these settings by the government, each firm will trade the permits to minimize its cost, which is the summation of treatment cost and permit cost. By this process, the overall cost to society of pollution abatement will be minimized. Since emissions trading programs put a ceiling or a cap on the total amount of pollutants and emitters trade permits within the cap, they are called "cap-and-trade" programs, which are the most common type of emissions trading.

A variation is called "baseline-and-credit" or "emission reduction credit" programs, which focus on transactions on a case-by-case basis or on a project basis. In these programs, emission reduction credits are created in cases where actual emissions are below the baseline. The baseline is the level of emissions that would occur in the absence of the proposed project. Whether this type of programs work properly depends on the appropriate setting of the baseline. Inappropriate setting of the baseline is likely to cause emission increase and unfair credits.

A third variation is to express environmental targets in terms of pollutant concentration at each receptor and to define permits accordingly. Under this system ambient, or impact-based, permit systems, are developed ${ }^{2}$. An ambient permit authorizes the holder to worsen pollutant concentration at each receptor by a fixed unit amount, unlike emission permits. Accordingly, ambient permit systems require as many markets of the ambient permits as the number of receptors.
They also require impact separability, i.e. that the impact at a receptor be expressed as a sum of impacts from individual emitters. Under these systems, each emitter will try to minimize its financial cost while considering how much impact its discharged pollutants have on each receptor.

In theory, these programs have the advantage that the set of exchanges that emerges from this market in impact-based permits constitutes the least-cost way of meeting the ambient standard. In practice, however, ambient permit systems suffer from the difficulties of transaction complexity and uncertainty of impact coefficients. Hence, the first or second variation, either of which allows dischargers to emit a mass unit of pollutants, are usually used in emissions trading programs, rather than ambient permits. This does imply, however, that, since it is the aggregate emissions rate of all emitters that is controlled, rather than the environmental impact, these permit systems can result in "hot spots" where emissions concentrate due to emissions trading.

\section{AN OVERVIEW OF EMISSIONS TRADING IN THE UNITED STATES}

This Chapter presents an overview of the mechanisms and performance of emissions trading programs which have actually been implemented in the United States to date. Six programs, including the $\mathrm{SO}_{2}$ allowance trading program, are analyzed and compared.

\section{(1) Air emissions and water pollutants trading programs}

In the United States, trading programs of air emissions and water pollutants have been designed and implemented so $\mathrm{far}^{3}$. . Under the Clean Air Act, the air emissions trading program was introduced in 1977. Developed from the "command-and-control" approach in the Clean Air Act, the air emissions trading program focuses on transactions at a plant or local level on a case-by-case basis. There is no market, which works under the total emission cap on regions. Therefore, the program is classified into the "baseline-and-credit" type, which uses the emission standards or current emission levels as the baseline. The baseline is set at the level of the emission standards. The target pollutants are the criteria pollutants cited in the Clean Air Act, including $\mathrm{SO}_{2}, \mathrm{NO}_{x}$, particulate matter, carbon monoxide, and volatile organic compounds (VOCs). It can be observed that air emissions trading programs generally impose some significant limitations on trading, including application of 
emission standards, restrictions on the trading area, or requiring air quality modeling to assure that air quality will not be deteriorated. Due to these restrictions, the hot-spot issue, by which emissions move to an unfavorable location, does not arise in trading emission reduction credits.

The lead trading program was instituted in 1982 at a national level to decrease the content of lead in gasoline, allowing refiners to trade the credits calculated by subtracting the actual amount of lead content of their gasoline from the standard. Under this "cap-and-trade" program in the upstream sector, the credits had been actively traded both internally and externally until 1987, the end year of the program, and large cost savings were attained while decreasing the total amount of lead in the US gasoline supply ${ }^{4)}$.

A "cap-and-trade" program termed "RECLAIM" (Regional Clean Air Incentives Market) was established in 1993 in the Los Angeles area to meet the standard of ground-level ozone concentration. The target pollutants are $\mathrm{NO}_{\mathrm{x}}$ and $\mathrm{SO}_{\mathrm{x}}$ from stationary sources. In the program, there are two restrictions on trading, one geographic and one temporal $^{5)}$. The geographical restriction prohibits sources in coastal zones from obtaining credits from inland sources with the aim of preventing the shift of emissions from downwind to upwind locations. The temporal restriction is that banking credits is not allowed in order to avoid "temporal hot spots," or days on which aggregate emissions might be higher than planned for.

The BOD effluent trading program for the Fox River, Wisconsin was initiated in 1981 in order to meet the environmental standard of the river to which point sources such as paper mills and municipal wastewater treatment plants were discharging their wastes. In this "cap-and-trade" program, there are some significant restrictions on trading such as a government approval process, resulting in only one trade under the program so $\mathrm{far}^{6}$.

The phosphorus effluent permit trading for the Dillon Reservoir, Colorado was introduced in 1984 to cope with eutrophication in the reservoir. This "cap-and-trade" program provides phosphorus loading allowances to four municipal wastewater treatment plants that discharge wastes into the reservoir. The program preferentially encourages reduction of phosphorus discharges from non-point sources, because that type of reduction is significantly less costly than that of point source controls. However, because of the relative uncertainty of non-point source control, the program requires a $2: 1$ ratio of nonpoint-to-point source control. If a point source needs one allowance to offset its discharge beyond the allocated level, the program allows them to obtain the credits created from reduction of phosphorus from non-point sources, but requires that they purchase two allowances.

\section{(2) $\mathrm{SO}_{2}$ Allowance Trading Program}

The 1990 U.S. CAAA set up the $\mathrm{SO}_{2}$ allowance trading program as one of the Acid Rain Programs with the intention of reducing $\mathrm{SO}_{2}$ emissions mainly from coal-fired power plants at a national level in a cost-effective manner. The $\mathrm{SO}_{2}$ allowance determines the amount of $\mathrm{SO}_{2}$ emissions that emitters are allowed to emit. This is a nationalscale "cap-and-trade" program in $\mathrm{SO}_{2}$ allowances. Allowances allocated by grandfathering can be traded as long as actual emissions meet the Federal or state $\mathrm{SO}_{2}$ emissions standards set for human health. If the actual $\mathrm{SO}_{2}$ emissions are below the allowances, the allowances remaining after the deduction can be sold or "banked." If the actual $\mathrm{SO}_{2}$ emissions are beyond the allowances, emitters have to pay a penalty of US $\$ 2000$ (adjusted for inflation) per excess ton of $\mathrm{SO}_{2}$ and purchase $\mathrm{SO}_{2}$ allowances equivalent to excess ton of $\mathrm{SO}_{2}$.

The $\mathrm{SO}_{2}$ allowance trading program is divided into two phases as a strategy to tighten the restrictions gradually. Phase 1 , begun in 1995, affected 263 units at 110 dirty, coal-fired power plants in the Northeast and Midwest. In Phase 2, which began in 2000 , stricter emission limits have been imposed on more units than Phase 1. Figure 1 derived from Smith et $\mathrm{al}^{7)}$ illustrates the scenario of the emission cap and the optimal emission path. The "optimal" emission path is the emission curve that the EPA is projecting under the most optimistic scenario of emitters' behavior under the $\mathrm{SO}_{2}$ allowance trading program. The emission cap in Phase 2 is projected to be met after the year 2010, not 2000. The undercompliance in Phase 2 is likely to be mitigated by banking from the over-compliance in Phase 1 .

Since the overall emission cap cannot be increased, newcomers, defined as those who began power production after 1996, are given no free allowances, unlike existing emitters, nor, of course, are environmental groups ${ }^{8)}$. Therefore, newcomers have to purchase allowances from existing sources, from brokers, or from annual EPA auctions. It is undeniable that the matter of equity between existing sources and new sources remains a concern. Since the year 1993, when $\mathrm{SO}_{2}$ allowance auctions were started prior to Phase 1 , the $\mathrm{SO}_{2}$ allowance trading program has successfully contributed to the reduction of $\mathrm{SO}_{2}$ emissions. Figure 2 derived from the EPA report ${ }^{9)}$ illustrates the change of $\mathrm{SO}_{2}$ emissions from Phase 1 affected units. 


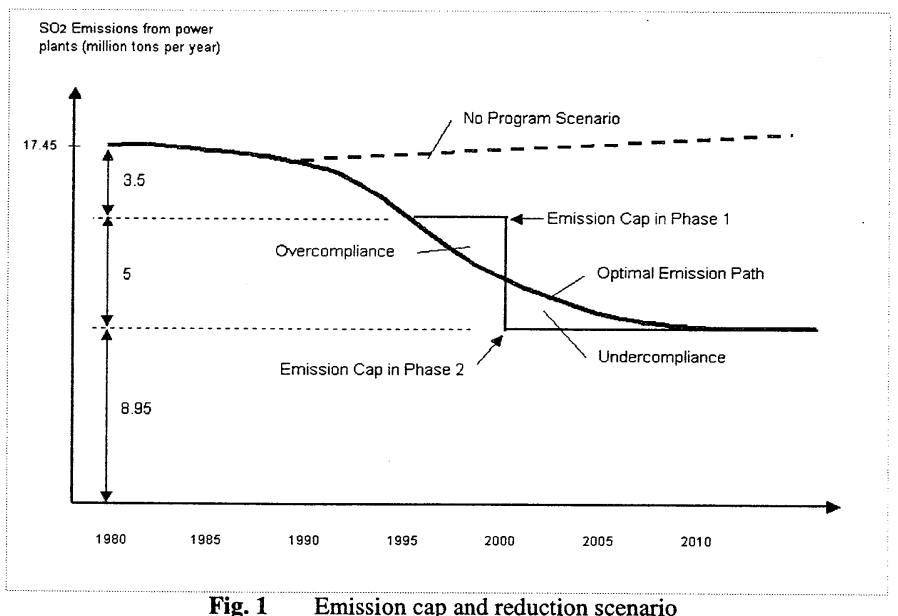

(Reprinted with permission from Public Utilities Reports, Inc., from May 15, 1998 issue of Public Utilities Fortnightly)

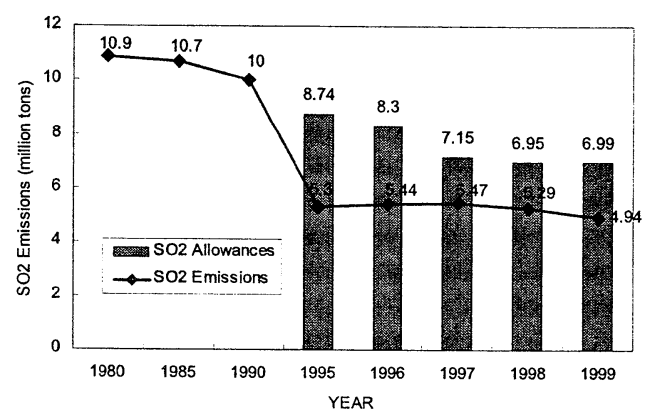

Fig. $2 \mathrm{SO}_{2}$ Emissions and allowances from Phase 1 affected units

$\mathrm{SO}_{2}$ emissions decreased in 1995 , the beginning year of Phase 1 , and since then have been stable at a level below the allocated allowances. The decrease of $\mathrm{SO}_{2}$ emissions at a national level has resulted in the mitigation of acid rain ${ }^{10)}$. Although 'hot spots' have not been reported to date, the hot spot issue, including temporary hot spots caused by banked allowances, is still a concern.

\section{(3) Lessons from the emissions trading programs in the US}

Table 1 illustrates the characteristics of the six examples of emissions trading programs and seems to show four major points. One is that all programs adopt emission (effluent) permits which serve as emission (effluent) reduction credits, rather than concentration reduction credits. This is probably due to the complexity of ambient permit systems.

The second point, which is related to the first, is how the risk of hot spots is addressed. In cases where emission (effluent) permit programs are adopted for "non-uniformly mixed assimilative" pollutants, this is the most critical issue, and each program has unique features to deal with it. In the air emissions trading program, trading credits is limited to a same plant or area. RECLAIM and the BOD trading program need approval by the governments. The phosphorus effluent permit trading program set the trading ratio of $1: 2$ (although the reason for this is not just to address the hot spot issue, which was not a major consideration for this, a reservoir water quality program). Under the $\mathrm{SO}_{2}$ allowance trading program, emitters must be in compliance with the Federal and state $\mathrm{SO}_{2}$ emission standard. Because of these restrictions, a least-cost allocation has not been realized in most cases. Nevertheless, these restrictions seem to be needed to strike a balance between environmental protection and economic efficiency. Furthermore, it should be noted that allowing emitters to bank allowances for future use could cause "temporal hot spots."

The third point is types of emissions trading. Only the air emissions trading program is a "baselineand-credit" type, while the other programs are "capand-trade" ones. The critical point of "baselineand-credit" programs is setting baseline appropriately. In case of the air emissions trading program, there is no problem with the baseline because it is clearly set at the Federal or State emissions standards or current emissions levels.

The forth point is that all "cap-and-trade" programs adopt a grandfathering approach in distributing permits initially. When a new policy is embarked on, the government must convince existing emitters to some extent. Without the consensus, the policy could sometimes be impractical. The grandfathering approach appears 
Table 1 Features of six trading programs

\begin{tabular}{|l|l|l|l|l|l|}
\hline & $\begin{array}{l}\text { Target } \\
\text { Pollutants }\end{array}$ & $\begin{array}{l}\text { Type of } \\
\text { Program }\end{array}$ & $\begin{array}{l}\text { Type of } \\
\text { Permit }\end{array}$ & $\begin{array}{l}\text { Allocation } \\
\text { Method }\end{array}$ & Other Features \\
\hline $\begin{array}{l}\text { Air Pollutants } \\
\text { Emission Trading }\end{array}$ & $\begin{array}{l}\text { Criteria } \\
\text { pollutants } \\
\left.\text { (ex. } \mathrm{SO}_{2}\right)\end{array}$ & $\begin{array}{l}\text { Emission } \\
\text { reduction } \\
\text { credit }\end{array}$ & $\begin{array}{l}\text { Emission } \\
\text { permit }\end{array}$ & $\cdots$ & $\begin{array}{l}\text { Restrictions on } \\
\text { trading }\end{array}$ \\
\hline Lead Trading & $\begin{array}{l}\text { Lead in } \\
\text { gasoline }\end{array}$ & $\begin{array}{l}\text { Cap and } \\
\text { trade }\end{array}$ & $\begin{array}{l}\text { Emission } \\
\text { permit }\end{array}$ & $\begin{array}{l}\text { Grand- } \\
\text { fathering }\end{array}$ & $\begin{array}{l}\text { Time-limited } \\
\text { program }\end{array}$ \\
\hline RECLAIM & $\mathrm{SO}_{\mathrm{x}}$ and \\
$\mathrm{NO}_{\mathrm{x}}$ & $\begin{array}{l}\text { Cap and } \\
\text { trade }\end{array}$ & $\begin{array}{l}\text { Emission } \\
\text { permit }\end{array}$ & $\begin{array}{l}\text { Grand- } \\
\text { fathering }\end{array}$ & $\begin{array}{l}\text { Variable trading } \\
\text { ratio }\end{array}$ \\
\hline $\begin{array}{l}\text { BOD Trading in the } \\
\text { Fox River }\end{array}$ & $\mathrm{BOD}^{\text {Cap and }}$ & $\begin{array}{l}\text { Effluent } \\
\text { permit }\end{array}$ & $\begin{array}{l}\text { Grand- } \\
\text { fathering }\end{array}$ & $\begin{array}{l}\text { Restrictions on } \\
\text { trading }\end{array}$ \\
\hline $\begin{array}{l}\text { Phosphorus Trading } \\
\text { in Dillon Reservoir }\end{array}$ & $\mathrm{Phosphorus}^{\text {trade }}$ & $\begin{array}{l}\text { Cap and } \\
\text { trade }\end{array}$ & $\begin{array}{l}\text { Effluent } \\
\text { permit }\end{array}$ & $\begin{array}{l}\text { Grand- } \\
\text { fathering }\end{array}$ & $\begin{array}{l}\text { Point/nonpoint } \\
\text { sources trading }\end{array}$ \\
\hline $\begin{array}{l}\text { SO }{ }_{2} \text { Allowance } \\
\text { Trading }\end{array}$ & $\mathrm{SO}_{2}$ & $\begin{array}{l}\text { Cap and } \\
\text { trade }\end{array}$ & $\begin{array}{l}\text { Effluent } \\
\text { permit }\end{array}$ & $\begin{array}{l}\text { Grand- } \\
\text { fathering }\end{array}$ & $\begin{array}{l}\text { National-scale } \\
\text { program }\end{array}$ \\
\hline
\end{tabular}

to cause less conflict with emitters compared to sales. In cases where allowances are sold by the government, financial costs to emitters can be even greater than those under "command-and-control" approaches. In addition, inappropriate allocation of allowances should be avoided in order not to provide unfair benefits to part of emitters.

Next, it seems meaningful to analyze the $\mathrm{SO}_{2}$ allowance trading program in detail, because the nation-wide program can be a harbinger of largescale emissions trading. The reasons that the program has contributed to the reduction of $\mathrm{SO}_{2}$ emissions are likely to be the following: less restriction, proportion of covered emissions, credibility, transparency, and flexibility. With respect to the restriction on trading, the program is not limited to a plant level or a local area level but extends to a national level. While each source is subject to the Federal or state $\mathrm{SO}_{2}$ emission standards, this limitation does not appear to have affected the performance significantly, because the range of the emission standards is large. Sufficient coverage of emissions ensures environmental effectiveness by the emissions trading. Coal-fired power plants under the program account for most of $\mathrm{SO}_{2}$ emissions in the US. In order to ensure credibility and transparency, the program requires emitters to install $\mathrm{SO}_{2}$ monitoring systems and report their $\mathrm{SO}_{2}$ emissions to the EPA. The reported data are disclosed on the EPA web-site. Flexibility implies that there are versatile approaches to reducing $\mathrm{SO}_{2}$ emissions, which results in a great difference in the marginal costs of $\mathrm{SO}_{2}$ removal. $\mathrm{SO}_{2}$ can be reduced in various ways: substituting low-sulfur coal for high-sulfur coal, converting a coal-fired power plant to a gas-fired power plant, improving heat efficiency, installing $\mathrm{SO}_{2}$ removal equipment, and so on. This fact is likely to enhance the activity of the allowance market. Moreover, technology development incentives can be provided by trading programs, since emitters seek to reduce $\mathrm{SO}_{2}$ emissions as cheaply as possible.

\section{EMISSIONS TRADING IN JAPAN}

In Japan, emissions trading has not been popular so far, although it has been a subject of academic research. Official programs of emissions trading do not exist in either national or local environmental regulations in Japan. However, there are policies and measures that partly include the essence of emissions trading. One example is pollution control agreements between local governments, large-scale factories and residents. Pollution control agreements have usually played a significant role in improving the local environment by limiting the mass of air and/or water pollutants emitted from factories. In other words, industries are required to limit their emissions below the agreed amounts in their plants, even if they construct new facilities or upgrade existing facilities. This rule can be said a type of internal emissions trading although it does not necessarily entail financial transactions.

In fact, GHG emissions trading under the Kyoto Protocol will take place from 2008. As a Party to the Protocol, Japan will participate in the emissions trading. While emissions of greenhouse gases (GHGs) such as $\mathrm{CO}_{2}$ cause climate change on a global scale, the impact is independent of the location where the gases are emitted. Therefore, GHG emissions trading programs could not result in hot spots.

In parallel with international GHG emissions trading, domestic emissions trading programs are increasingly drawing attention as an approach to reduce GHG emissions. The Ministry of the Environment, Japan, is testing a "cap-and-trade" type of domestic emissions trading from 2003 with voluntary participation. The trading will be implemented on a trial basis without financial 
transactions. However, some industries seem to be concerned about a "cap-and-trade" type of emissions trading. They consider a cap on each industry's emissions as new regulation since there are currently no "command-and-control" regulations on GHG emissions. In particular, they are likely to consider the caps on their emissions as the ones on their activities, since controlling $\mathrm{CO}_{2}$ is directly related to most economic activities.

As a matter of fact, regulation by a mass unit of pollutants is probably stricter on emitters than by emission concentration. Under emissions concentration regulations, emitters have flexibility to adjust the concentration of pollutants by such measures as shifting operating time of sources. In contrast, regulation by a mass unit does not allow such control of emission concentration.

Apart from GHG emissions trading, are there environmental problems that could be alleviated by the approach of emissions trading in Japan? Considering the lessons from US emissions trading programs, important elements required for emissions trading programs would include the necessity to reduce total pollutants at a national or regional level, and environmental effectiveness realized by adequate coverage of emissions. In addition, emissions under the programs should be reviewed and disclosed to ensure credibility and transparency. If problems with the target pollutants depend on locations of sources, hot spot issues should be carefully taken into consideration. On the other hand, unnecessary restriction on trading should be avoided, striking a balance between environmental protection and economic efficiency.

The above elements relate to each other and have contributed to the satisfactory performance of the program collectively. Since each environmental problem has different aspects, it seems to be difficult to set definite standards for designing and implementing emissions trading programs. However, the above elements can be used as criteria in designing the framework of emissions trading programs.

Taking into account these elements, one of the promising areas for emissions trading is to improve water quality in enclosed sea areas by reducing discharges of Chemical Oxygen Demand (COD), nitrogen and phosphorus. Tokyo Bay, Ise Bay and Seto Island Sea are the biggest enclosed sea areas in Japan and receive pollutants from concentrated areas of population and industry. Water quality of the enclosed sea areas has not been improved significantly in spite of pollution control measures. Under the Water Pollution Control Law, therefore, the Area-wide Total Pollutant Load Control Program has been implemented to seek an overall reduction of pollutants flowing into those areas. This policy means to put caps on total amounts of pollutants, while the Water Pollution Control Law usually regulates effluent concentrations. The current target pollutants are COD, nitrogen and phosphorus. To meet water quality standards in the enclosed sea areas, further reduction of pollutant discharges are required in a cost-efficient manner. This is essentially the same scenario that prompted the Wisconsin Department of Natural Resources to initiate the Fox River program.

A "cap-and-trade" program could prove effective in this case. Total effluent caps of COD, nitrogen and phosphorus are already imposed on each enclosed sea area under the Water Pollution Control Law. Therefore, tradable discharge permits could be provided to large-scale dischargers based on the caps and a market for each sea area could be created. While domestic effluent loading exceeds those of industrial effluents for the three pollutants in all areas, considerable amounts of the pollutants could be covered by including sewage treatment plants, community plants and agricultural community effluent treatment facilities.

The most critical issue is to avoid hot spots under the trading programs. Hence, dischargers should be subject to existing effluent standards. In particular, explosive propagation of algae, which results in deteriorating water quality, occurs frequently in summer. Limits on the movement of effluent permits in summer are likely to be needed.

Non-point sources and household effluents should also be considered. If they are included in the trading programs, there could be more improvement of water quality. Following the Dillon Reservoir example, point source dischargers could be issued effluent permits upon their reduction of pollutants from non-point sources. Trading ratios between COD, nitrogen and phosphorus can be developed in order to reduce the pollutants more cost-efficiently. These ratios should be calculated as scientifically as possible.

With regard to air pollution, total mass control of NOx emissions from factories has been implemented under the Air Pollution Control Law in the areas where environmental quality standards of NOx are not in compliance. While air quality standards are exceeded in a number of urban areas, the pollution is mainly due to emissions from motor vehicles. Because it is difficult to put emission caps on each vehicle, "cap-and-trade" programs for NOx reduction does not seem to result in air quality improvement. Actually, a variety of measures to reduce NOx emissions from motor vehicles have been implemented, including establishment of a specified vehicle exhaust standard. 


\section{CONCLUSION}

This paper has reviewed emissions trading programs and discussed key points in designing the programs. In emissions trading, a mass unit of pollutants has been used even for pollutants which could have an adverse effect on the environment as a result of concentrated emission sources. In those cases, "hot spot" issues, including temporal hot spots, should be addressed. In order to avoid these hot spot issues, restrictions on trading are sometimes required. These restrictions often result in a trade-off with cost efficiency.

In "cap-and-trade" programs, a grandfathering approach is common to provide allowances for emitters. Since grandfathering is often advantageous to existing emitters, equity of emitters should be taken into consideration as well as appropriate allocation of allowances. In "base-andline" programs, proper setting of the baseline is essential to function of the programs. As the $\mathrm{SO}_{2}$ allowance trading program shows, less restriction, credibility, transparency, and flexibility are essential to designing emissions trading programs with technology development incentive.

Based on the lessons from US experiences, one of the promising areas for emissions trading in Japan is to reduce water pollutants discharged into the enclosed seas, apart from GHG emissions trading. In designing the emissions trading programs, hot spot issues and involvement of non-point sources would be key elements to be considered.

\section{REFERENCES}

1) Dales, J. H. : Property \& Prices: An Essay in Policy-making and Economics, University of Toronto Press, pp. 93-108, 1968.

2) Tietenberg H. T. : Emissions Trading -an exercise in reforming pollution policy-, Washington, D.C.: Resources for the Future, pp. 60-92, 1985.

3) U.S. Environmental Protection Agency (EPA) : The United States Experience with Economic Incentives for Protecting the Environment, Report EPA/240-R-01-001, Washington: Office of the Administrator, 2001.

4) Hahn, R. W. and G. L. Hester. : Marketable Permits: Lessons for Theory and Practice. Ecology Law Quarterly, Vol 16, pp. 361-406, 1989.

5) Harrison, D. Jr. : Turning theory into practice for emissions trading in the Los Angeles air basin, In Pollution for Sale: emissions trading and Joint Implementation, edited by $\mathrm{S}$. Sorrell and J. Skea, pp. 63-79, Northhampton: Edward Elgar Publishing, Inc., 1999.

6) U.S. Environment Protection Agency (EPA) : Draft Framework for Watershed-based Trading. Report EPA/800R-96-001, Washington: Office of Water, 1996.

7) Smith, E. A., J. Platt, and D. A. Ellerman. : The Cost of Reducing $\mathrm{SO}_{2}$ (It's Higher Than You Think), Public Utilities Fortnightly, Vol. 136 (15), pp. 22-29, 1998.

8) U.S. Environmental Protection Agency (EPA) : Acid Rain Program: $\mathrm{SO}_{2}$ emissions trading Program, http://www.epa. gov/acidrain/trading.html (May 2000 accessed), 2000.

9) U.S. Environmental Protection Agency (EPA) : 1999 Acid Rain Program Compliance Report, Report EPA/ 430-R-00007, http://www.epa.gov/airmarkets/cmprpt/arp99/index. html (July 2001 accessed), 2000.

10)National Atmospheric Deposition Program (NRSP3)/National Trends Network. : http://nadp.sws.uiuc. edu/isopleths (accessed March 2001), 2001.

\section{処理コスト削減手段としての排出量取引}

\section{瀧口＼cjkstart博明 - J. Wayland Eheart}

污染物質を費用効果的に削減できる排出量取引について、米国での代表例を分析し、ほとんどの例が 排出枠の配分方法としてグランドファザリング方式を採用していること、污染物質の集中を避けるため に取引に制限を加えていること、排出量取引の成否は取引に関する規制の少なさや信頼性、透明性、柔 軟性によることなどを明らかにした。また、日本における排出量取引導入の可能性を論じるとともに、 閉鎖性海域の水質保全のために排出量取引を導入することについて考察した。 